JEL: Q10, Q15, Q57

\author{
Nataliia Maslak ${ }^{1}$, Zhang Lei ${ }^{1}, \mathrm{Lu} \mathrm{Xu}^{2}$ \\ ${ }^{1}$ Sumy National Agrarian University \\ ${ }^{2}$ Henan Institute of Science and Technology \\ ${ }^{1}$ Ukraine \\ ${ }^{2}$ China
}

\title{
ANALYSIS OF AGRICULTURAL TRADE IN CHINA BASED ON THE THEORY OF FACTOR ENDOWMENT
}

Purpose. The purpose of the paper is to present the results of the study of agricultural trade in China based on the theory of factor endowment and to develop a policy recommendation for the intensification of agricultural trade based on technological progress.

Methodology / approach. This paper uses the methods of economic theory and comparative analysis to study the development of agricultural products trade in China; analysis the advantages of developing agricultural products trade in China by using comparative advantage theory; and econometric analysis to study the relationship between volume of agrarian trade and agricultural labor force, capital and land resources.

Results. This paper uses time series data to analyze the three elements of capital, labor and land, and the development of agricultural trade in China. According to the established data model, it is obviously that China's agricultural production of land factor endowment constraints are obvious, labor factor endowment is abundant but also facing the problem of increasing costs, labor personnel gradually decline. In this case, technological progress is more critical to the cultivation and maintenance of comparative advantage of agricultural products. The government should guide the direction of technological changes, technical support, capital support (material capital and human capital); and promote the rapid development of China's agricultural trade.

Originality / scientific novelty. Author's developed econometric model is very useful in empirical assessment for the China agricultural products trade development, and it also provides new decisions for China to develop agricultural trade. Accordingly, the proposed method can provide an answer to the question of how to develop traditional agriculture in the context of rapid economic changes, and put forward more practical countermeasures.

Practical value / significance. The main proposals can be used by the Government of China to formulate better agricultural trade policies and achieve rapid economic growth and increasing farmer incomes.

Key words: agricultural products, econometric models, factor endowments.

Introduction and review of literature. With the globalization of the world economy and the development of regional integration, the economic and trade exchanges between countries and regions are becoming more and more close $[1 ; 2]$. Agricultural trade is an important part of the world economy. Therefore, the changes in the international market have a profound impact on the development of agriculture and agricultural products of foreign trade in various countries and regions. Internationalization is the development trend of agriculture in the world today. It refers to the whole process of agricultural industry reproduction, including the 
production, exchange, distribution and consumption of agricultural products, which has been expanded from one country to the world, realizing the transnational flow of factors of production and agricultural products, the global allocation of resources, and gradually strengthening the integration of agricultural investment and trade with the world market.

Factor endowment theory is the foundation and pillar of modern comparative advantage theory $[3 ; 4 ; 5]$ and it is based on the study of the change of comparative advantage of various elements. Factor endowments include:

Natural resource endowment. Natural resources are the source of exogenous comparative advantage in a complete sense, such as land area, geographical location, water power, mineral deposits and other innate determinants belong to this, and won't be changed with the change of social era and economic development. Geographical location has important influence on the market, supply and transportation cost of international trade. The endowment of natural factors is the initial condition for the development of international trade [6;7].

Labour force. The endowment of the labor force is determined by the natural growth rate of the population of a country or region, that is, the birth rate, and it is also not determined by the economic and social development. In the reality of trade, labor force becomes the source of comparative advantage, which is mainly manifested in the comparative advantage of export products formed by the low labor cost of low-wage countries or regions, thus forming a comparative advantage in labor-intensive industries and successfully obtaining trade benefits in the world market. This is evident in the rise of Asian economies.

Capital element. Like labor, capital is an important source of comparative advantage. Formally, capital is divided into material capital and human capital. Different from the labor force, if the change of time is not considered, capital is the exogenous variable of the change of comparative advantage, but in the process of production, because capital is the amount of capital that can be produced and recycled investment, there is a process of gradual accumulation with the change of time, so it is an endogenous factor for comparative advantage.

Under the guidance of liberal economic development thought, the globalization of economic activities is deepening day by day, and the economic system of various countries is gradually converging. At the same time, the development of modern science and technology is advancing by leaps and bounds, which provides a strong material support for the operation of economic system [8]. In this context, the internationalization of world agricultural development has become an irreversible trend. From the beginning of the reform, China's agriculture began to integrate into the international system, and joining is a big step forward on the road of internationalization. In the process of agricultural internationalization, the depth and breadth of China's external agricultural expansion has gradually increased, which has the opportunity to make full use of both domestic and international resources and markets, as well as to face the opportunities from the pressure and challenges of the world market. 
China is typical of these transition countries. First of all, since 1978, it was experienced a historic transformation from closed doors to open, joining the WTO marked the continuous integration of China and the international market, the domestic market, thus becoming an important member of the world free trade. Secondly, since the mid-1980s, China has established the policy of transition from planned economy to market economy, and the reform of economic system has been moving forward continuously. Finally, cultivated land and labor force are the most important «elements» of agricultural production, and China does not have the natural advantages of «natural endowment» such as cultivated land and water resources. Deterioration of the environment, making available superior quality agricultural resources are scarce [9]. The labor force is abundant, but its cost, along with the national income increases, unceasingly grows.

The theory of «factor endowment» is carried out from the different natural environment and historical development of different countries and regions, which affects the structure of national trade. The theory provides the creation of a $2 * 2 * 2$ model, according to the density of national elements, the establishment of production functions, analysis of the differences in national product supply capacity, so as to draw a conclusion. A country exports products of intensive use, rich elements, and imports products of intensive use, scarce elements. The specific analysis is as follows (Fig. 1): under the condition of complete competition, other unchanged, in the $A^{\prime} B$ two countries, the production $X^{\prime} Y$ two commodities; according to the premise of the model hypothesis, $A$ countries are capital rich countries, $B$ countries are labor rich countries, $X$ - capital intensive countries products, $Y$ - labor-intensive products. Since $A^{\prime} B$ two countries have different factor endowments, the boundary of production possibility is $A A$, and $B B^{\prime}$. A relative demand curve and a relative supply curve determine the relative price level $P_{A}, P_{B}[2 ; 5 ; 9]$.

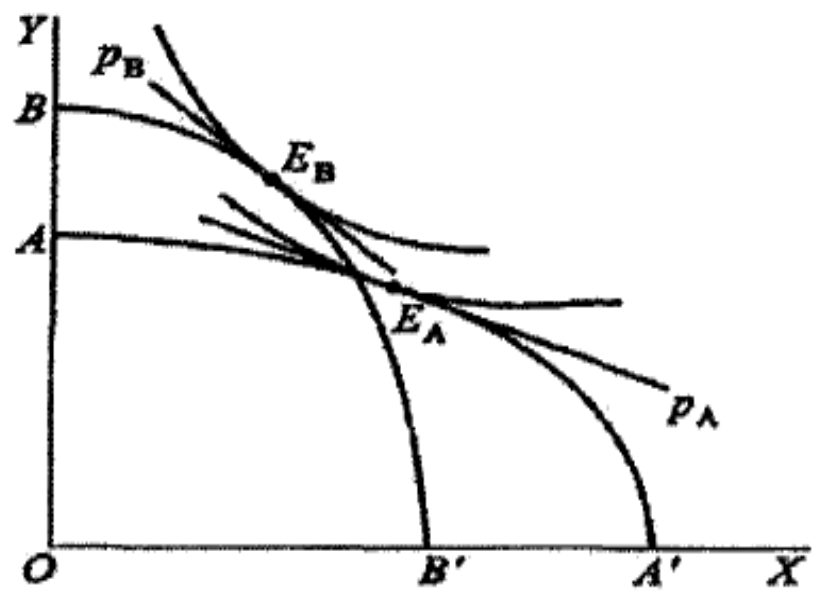

Fig. 1. Theory of Factor Endowment

Source: compiled based on $[2 ; 5 ; 9]$.

Under the situation of idle conditions, we can see from the diagram that the equilibrium point of A country under closed condition is $E A, B, P_{A}<P_{B}$ at this time. Since the opening up, the relative price of $X$ products in $B$ countries is relatively high, so $A$ countries talk about the $B$ countries exporting the products, and, at the same 


\section{Agricultural and Resource Economics}

www.are-journal.com

time, the countries exporting $Y$ products to $A$ countries; exports of $X$ products will simply reduce domestic supply, thus $X$ relative prices rise, by the same token, $B$ country knows until equilibrium [10].

The purpose of the article. The purpose of the paper is to present the results of the study of agricultural trade in China based on the theory of factor endowment and to develop a policy recommendation for the intensification of agricultural trade based on technological progress.

Results and discussion. With the rapid economic development, the agricultural trade problem is becoming more and more prominent, and its specific problems are as follows:

1. Population increased demand for agricultural products. It is reported that by 2050 , the world population is likely to increase by another billion, and if the demand for this growth is to be met, food will need to increase by that time. The main rate of world population growth comes from developing countries, where demand for agricultural products is growing faster, and where urbanization can also lead to changes in the food structure; the future demand for agricultural products is more pronounced in developing countries. In addition, owing to inadequate capacity, some of the poorer countries are not self-sufficient in the growth of their agricultural demand and are more dependent on imports. As a result, the growth of the world's population, especially in developing countries, has contributed to China's agricultural exports more room for growth [11].

2. Market prospect of organic agricultural products [11; 12]. Organic agricultural products have been popular in recent years, mainly in North America and Europe. Sales of organic food and beverages worldwide are growing at a rate of 5 billion USD a year. However, the global state of acute shortages of organic agricultural products has not changed for years, such as cereals, herbs, beverages, vegetables, fruits and so on. Therefore, the market space of organic agricultural products in the future is broad. China has ten thousand hectares of organic land and is one of several countries with the largest organic land area, which provides natural resources for the production and trade of organic agricultural products in China source endowment advantage.

3. Bilateral trade is developing rapidly $[12 ; 13 ; 14]$. China has signed bilateral trade agreements with many countries or regions, while bilateral trade agreements with some countries are under negotiation, and some projects are under study. When the development of free trade is blocked, bilateral free trade agreements play an important role in promoting China's agricultural product import and export growth. The signing and implementation of bilateral free trade agreements have effectively improved the agricultural trade environment and improved the convenience of bilateral trade. FTAA has also implemented preferential policies for bilateral agricultural import and export enterprises to reduce their trade costs. The establishment of bilateral free trade zones provides a broad platform for the development of trade unions (especially complementary agricultural trade).

4. Non-tariff barriers restrict the growth of labor-intensive agricultural exports 


\section{Agricultural and Resource Economics}

www.are-journal.com

$[15 ; 16]$. Because of the lack of comparative advantage of land-intensive agricultural products and the maintenance of net import situation, the burden of more agricultural export trade is placed on the labor-intensive agricultural products with comparative advantage. With the adjustment of domestic agricultural market structure, the production of superior products will continue to grow, and the dependence on export market will be stronger. However, the export market, which is mainly developed countries, has put many obstacles on the export of labor-intensive agricultural products such as Chinese horticultural products. In the process of international trade liberalization, this barrier has shifted from tariff to non-tariff barriers, which the forms are becoming more and more diversified and the door is becoming more and more extensive, such as technical standards, environmental standards, national health standards, product certification and inspection procedures and other barriers are constantly strengthened, and the use of special insurance measures and anti-dumping litigation is becoming more and more frequent. These non-tariff barriers have caused serious obstacles to the growth of China's agricultural exports.

The theory of comparative advantage is the most important research achievement in the field of international trade. Its importance is embodied in three aspects: first, it extends from exploring the relationship between factor abundance and factor density and trade structure to the problem of resource allocation under open conditions under the framework of general equilibrium, from the study of the relationship between factor price and product price to the collection. The problem of income distribution is open microeconomics; secondly, in the process of general equilibrium analysis, the «structural general equilibrium analysis framework» has laid its theoretical benchmark position in the theoretical system of international trade, and the relevant rich and classical research results are based on it; third, the phenomenon of international trade and division of labor in reality has strong explanatory power and guidance.

With the development of economic theory, comparative advantage theory also has its own evolution process in different periods (1). Classical comparative advantage theory refers to the period of classical trade theory before the marginal revolution, which is the budding and birth period of comparative advantage theory. In this period, we have to mention the ancestor of western economics, which has played a catalytic role in the birth of the theory of comparative advantage: his theory of absolute advantage has opened up a new perspective of theoretical research, and at the same time has left space for the theory of comparative advantage, valuable, its point of view also contains the spark of thought of comparative advantage theory (2). The early neoclassical comparative advantage theory, Marshall, Echvos and others $[12 ; 13 ; 14]$ inherited ideas to contribute to the development of the theory, and the real formation of the neoclassical comparative advantage theory, which started from the theory of factor endowment, Olin and others $[15 ; 16]$ in the development of comparative advantage theory. The factor endowment theory introduces Valas general equilibrium analysis method into international trade theory $[3 ; 10]$, and puts forward different theories of comparative advantage: the difference of factor 


\section{Agricultural and Resource Economics}

www.are-journal.com

endowment causes trade among countries, each country exports products that use their abundant factors intensively, imports products that use their scarce factors intensively, so as to establish its own comparative advantage and trade mode in international trade by exerting the cost advantage of their respective export products.

The comparative advantage of agricultural products in the world market is basically manifested in the price advantage, which is determined by the production cost, circulation cost and additional cost in the whole link from input-output to entering the sales market. To simplify the analysis, we assume that the circulation cost and cost are zero, and the product price is determined only by the production cost. The core idea of factor endowment theory is that products with export-intensive use of high-margin factors of production have a comparative advantage in the international market, because high-margin factors of production have lower production costs, and thus their products have lower prices in the international market than other exporting countries can gain a comparative advantage. The importance of various elements in agricultural production was analyzed above. The following uses the production function to analyze the internal relationship between factor input and agricultural production cost.

It is assumed that agricultural factors of production consist of natural resources, capital and labor, in which land is used to represent all natural resources. When the output is constant and there are no economies of scale, the production cost of agricultural products is expressed in the following functions:

$$
C(L, K, A)=P_{L} L+P_{K} K+P_{A} A
$$

where $\mathrm{L}, \mathrm{K}, \mathrm{A}$ - denote labor input, capital input and land input respectively;

PL, PK, PA - denote labor price, capital price and land rent respectively. Assuming that the production function is a Cobb Douglas function $[17 ; 18]$ and the technology remains the same $Q=\mu L^{\alpha} K^{\beta} A^{\gamma}, \alpha+\beta+\gamma=1$ is constant.

The minimum value can be obtained:

$$
C(L, K, A)=\mathrm{c}(L, K, A)+\lambda\left(Q-\mu L^{\alpha} K^{\beta} A^{r}\right)
$$

Take the Lagrange function, order:

$$
\begin{aligned}
& \left\{\begin{array} { l } 
{ \frac { \partial C ( L , K , A ) } { \partial L } = P _ { L } - \lambda \alpha \mu A ^ { \alpha - 1 } K ^ { \beta } L ^ { \gamma } = 0 } \\
{ \frac { \partial C ( L , K , A ) } { \partial K } = P _ { K } - \lambda \beta \mu A ^ { \alpha } K ^ { \beta - 1 } L ^ { \gamma } = 0 } \\
{ \frac { \partial C ( L , K , A ) } { \partial A } = P _ { A } - \lambda \gamma \mu A ^ { \alpha } K ^ { \beta } L ^ { \gamma - 1 } = 0 } \\
{ \frac { \partial C ( L , K , A ) } { \partial \lambda } = Q - \mu A ^ { \alpha } K ^ { \beta } L ^ { \gamma } = 0 }
\end{array} \Rightarrow \left\{\begin{array} { l } 
{ P _ { A } A = P _ { K } K } \\
{ P _ { L } L = P _ { K } K }
\end{array} \Rightarrow \left\{\begin{array}{l}
A=\frac{P_{K}}{P_{A}} K \\
L=\frac{P_{K}}{P_{L}} K
\end{array},\right.\right.\right. \\
& Q=\mu L^{\alpha} K^{\beta} A^{\gamma}=\mu\left(\frac{P_{K}}{P_{L}} K\right)^{\alpha} K^{\beta}\left(\frac{P_{K}}{P_{A}} K\right)^{\gamma}=\mu \frac{P_{K}^{\alpha+\gamma}}{P_{L}^{\alpha} P_{A}^{\gamma}} K \Rightarrow K=\frac{Q P_{L}^{\alpha} P_{A}^{\gamma}}{\mu P_{K}^{\alpha+\gamma}}, \\
& \min C(L, K, A)=\frac{3 Q P_{L}^{\alpha} P_{K}^{\beta} P_{A}^{\gamma}}{\mu}
\end{aligned}
$$


where $\lambda$ - is the undetermined constant.

The minimum cost of agricultural products is determined by the price $P L, P K$, $P A$ of factors of production and the proportion $\mathrm{Q}$ factor combination, when the $\mathrm{Q}$ is constant, the cost of production is uniquely determined by the factor price. As a result, countries can gain a comparative advantage in international markets by concentrating their exports on products that use low-price factors of production.

Based on the Cobb Douglas production function model $[4 ; 17 ; 18 ; 19]$ considering the economic significance of the data, the linear model is obtained by taking the logarithm on both sides of the equation at the same time:

$$
\operatorname{In} Y=\operatorname{In} \theta+\operatorname{In} A^{\Upsilon}+\operatorname{InL}^{\alpha}+\operatorname{InK}^{\beta}
$$

where $\alpha, \beta$ and $\gamma$ respectively represent the contribution rate of each factor to the total assets, and bring in the related variables further [17]. We get the final measurement model as follows:

$$
\operatorname{InY}=\beta_{0}+\beta_{1} \operatorname{In} A+\beta_{2} \operatorname{InL}+\beta_{3} \operatorname{InK}+\mu
$$

where $\operatorname{In} \theta=\beta_{0}, \mathrm{Y}$ is annual total agricultural trade income;

$\beta_{1}, \beta, \beta_{3}$-as regression coefficient, $\mu$ as residual term.

Capital endowment. Capital is an essential element of any production activity. Compared with other products, agricultural products are usually not capital-intensive products, but only suitable capital inputs can make the factors of production such as land and labor play a higher productive efficiency [5;6]. The capital stock and its growth rate reflect the capital factor margin of a country (region), which affects the comparative advantage of production and trade.

Labour endowment. Agricultural production is the activity of putting labor into natural resources to produce products [3; 5]. The abundance of labor resources directly affects the comparative advantage of agricultural products, and countries (regions) with abundant labor resources are more likely to form a comparative advantage in labor-intensive agricultural products. China is the largest country with a large proportion of rural population, so it has always been considered to have the advantage of labor endowment in agricultural production and comparative advantage in labor-intensive agricultural products.

Land endowment. For agricultural products, the decisive role of land is in the first place of all factors, in the production of agricultural products, the endowment of land elements quantity and quality [5]. The former refers to the absolute size of the land area owned by a country (region). From this point of view, the endowment of land is limited and non-renewable, so it is a scarce factor for any country or region, and because land endowment is limited by territory and geography, the country (region) with small land area does not have the comparative advantage of land endowment in agricultural production. On the other hand, land factor endowment also refers to the soil within the land area owned. The differences in fertility, light, temperature, air, water and other conditions affect directly the natural productivity of agricultural products, and countries (regions) with fertile soil, good climate and other natural environment have the land endowment advantage of agricultural production.

Based on the above variables we derive the following data (Table 1). 


\section{Main indicators of the development of agriculture in China, 2011-2018}

\begin{tabular}{|c|c|c|c|c|}
\hline Year & $\begin{array}{c}\text { Annual total } \\
\text { agricultural trade } \\
\text { income (Y), } \\
\text { million CNY }\end{array}$ & $\begin{array}{c}\text { Capital input (K), } \\
\text { ten thousand CNY }\end{array}$ & $\begin{array}{c}\text { Labor input (L), } \\
\text { thousands CNY }\end{array}$ & $\begin{array}{c}\text { Land input (A), } \\
\text { thousands of } \\
\text { hectares }\end{array}$ \\
\hline 2011 & 452284 & 693198000 & 26594 & 61681 \\
\hline 2012 & 463428 & 894213473 & 25773 & 62490 \\
\hline 2013 & 491316 & 923425430 & 24171 & 63473 \\
\hline 2014 & 518238 & 985343682 & 22790 & 64539 \\
\hline 2015 & 504889 & 1070563648 & 21919 & 65872 \\
\hline 2016 & 519939 & 1093878680 & 21496 & 67140 \\
\hline 2017 & 531860 & 1101240339 & 20944 & 67815 \\
\hline 2018 & 551876 & 1379900000 & 20258 & 68271 \\
\hline
\end{tabular}

Source: Y (Q) data are from WTO website; K data are from the website of China Bureau of Statistics; L and A data are from the website of China Ministry of Rural Agriculture.

Stata and Views software were further used for regression analysis, and the results were as follows (Table 2).

Table 2

Variable regression results

\begin{tabular}{|c|c|c|c|c|c|c|c|}
\hline Source & SS & $d f$ & \multicolumn{2}{|c|}{ MS } & & $\begin{array}{l}\text { Number of obs } \\
\mathrm{F}(3, \quad 4)\end{array}$ & $\begin{array}{rr}= & 8 \\
= & 30.97\end{array}$ \\
\hline & 1 0200100 & & \multicolumn{2}{|c|}{.010313945} & & & \\
\hline Residual & .001332182 & 4 & \multicolumn{2}{|c|}{.000333045} & & R-squared & 0.9587 \\
\hline & & & & & & \multirow{2}{*}{$\begin{array}{l}\text { Adj R-squared } \\
\text { Root MSE }\end{array}$} & $=0.9278$ \\
\hline Total & .032274016 & 7 & .00 & 0574 & & & .01825 \\
\hline $\ln Y$ & Coef. & Std. & Err. & t & $P>|t|$ & [95\% Conf. & Interval] \\
\hline $\ln \mathrm{L}$ & -1.028626 & .4779 & 514 & -2.15 & 0.098 & -2.355632 & .2983795 \\
\hline $\ln A$ & -1.151775 & 1.103 & 353 & -1.04 & 0.355 & -4.215174 & 1.911623 \\
\hline $\ln K$ & .0434306 & .0977 & 056 & 0.44 & 0.680 & -.2278436 & .3147048 \\
\hline _cons & 35.32099 & 17.18 & 626 & 2.06 & 0.109 & -12.39573 & 83.03771 \\
\hline
\end{tabular}

Source: calculated by authors.
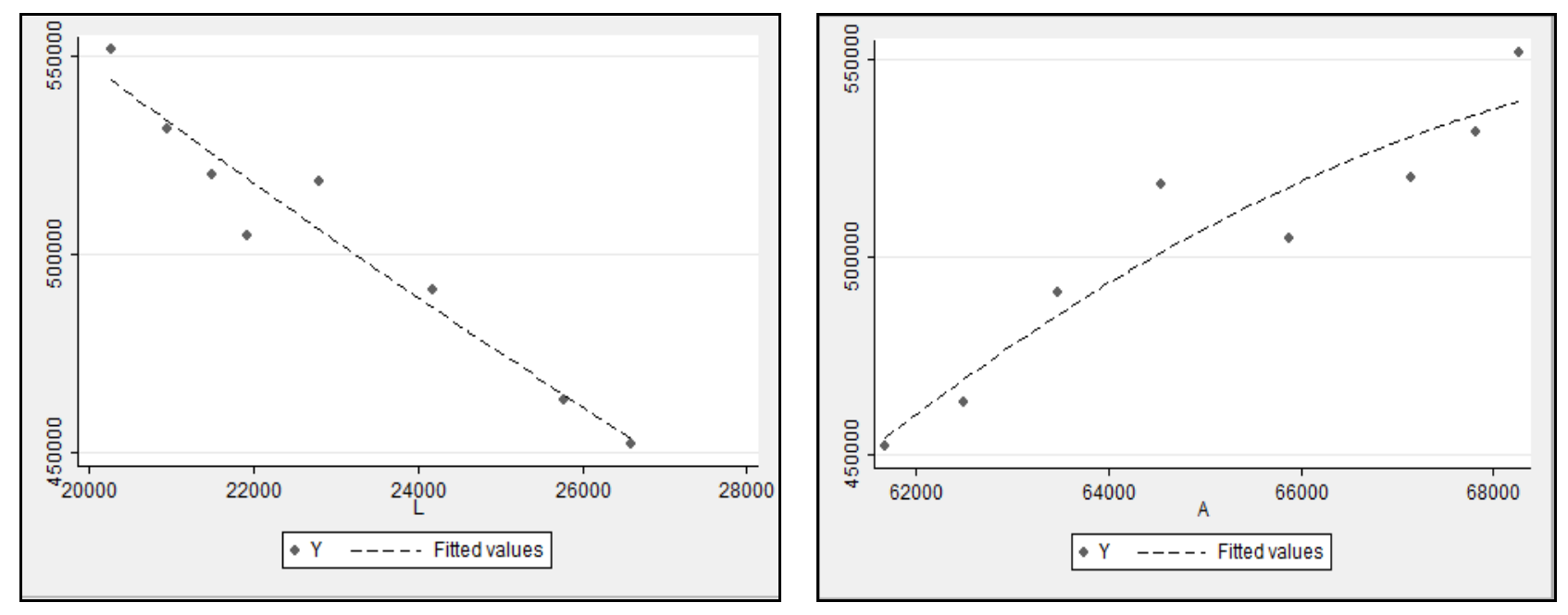


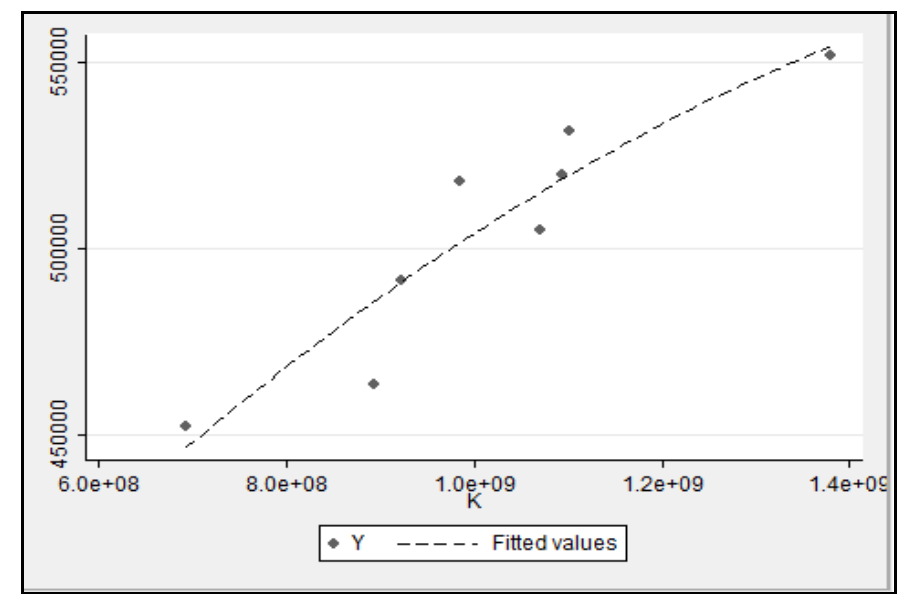

Fig. 2. Trends in fit between $K, L, A$ and $Y$ in China

Source: built by authors.

As a result of the study, the Cobb Douglas function has the following form:

$$
\text { InY }=35.32099-1.151775 \operatorname{In} A-1.028626 \operatorname{InL}+0.0434306 \mathrm{InK}+\mu
$$

So, regarding the $F$-test, the results indicated that the primary regression model $\mathrm{F}(3,4)=30.97$, and F-critical value of 30.97 at $5 \%$ significant horizontal degrees of freedom indicates that the overall model is highly significant.

The regression of panel data shows that the national land, labor and capital factor endowment plays an important role in supporting agricultural products and has a significant impact on agricultural trade. The developed econometric model is useful in empirical assessment for the China agricultural products trade development, and it also provides new decisions for China to develop agricultural trade. Accordingly, the proposed model can provide an answer to the question of how to develop traditional agriculture in the context of rapid economic changes, and put forward more practical countermeasures. The government should guide the direction of technological changes, technical support, capital support (material capital and human capital); and promote the rapid development of China's agricultural trade.

Conclusions. Land factor endowment constraints of China's agricultural production are obvious, labor factor endowment is abundant but also facing the problem of increasing costs, labor personnel gradually decline. In this case, technological progress is more critical to the cultivation and maintenance of comparative advantage of agricultural products. Agricultural technological progress is not the spontaneous product of the development of science and technology, but the dynamic reaction driven by the change of resource factor endowment, which is the result of the pursuit of maximum benefit and is not independent of the operation of economic system. Technological progress is the product of scientific research and development, and the trend of technological progress is the result of system guidance. Its specific responses are as follows:

1. The government should guide the direction of technological change according to the actual situation of resource endowment, but not completely let go factor price to guide technological development through market mechanism.

2. Technical support: financial support for technological innovation in the 
production, processing and service of target industries, encouragement of independent innovation by enterprises and strengthening of intellectual property protection; adjustment of the structure of the introduction of foreign capital, emphasis on technology introduction, shortening the gap with international advanced technology through technology spillover and learning effects; and vigorous development of agricultural technology extension.

3. Capital (material capital and human capital) support: strengthen the material capital accumulation of the industry by increasing the financial input to the target industry, perfecting the service and function of the policy finance, encouraging the moderate entry of foreign capital; improve the adaptability of human resources to industrial demand and strengthen the accumulation of human capital by strengthening the construction of rural basic education, farmers' professional and technical education and skills training.

The main recommendations can be used by the Government of China to formulate better agricultural trade policies and achieve rapid economic growth and increasing farmer incomes. The results also show that the use of comparative advantage in China's agriculture needs further research.

\section{References}

1. Yao, L., Fang, G., Wu, S. and Zhang, Q. (2012), Contribution of China's agricultural development to economic growth. Contemporary Economic Research, vol. 8, pp. 85-88.

2. Felipe, J. and Vernengo, M. (2002), Demystifying the principles of comparative advantage: implications for developing countries. International Journal
of
Political
Economy,
vol. 32,
no. 4 ,
pp. 49-75. https://doi.org/10.1080/08911916.2002.11042888.

3. Maneschi, A. (1992), Ricardo's international trade theory: beyond the comparative cost example. Cambridge Journal of Economics, vol. 16, no. 4, pp. 421437. https://doi.org/10.1093/oxfordjournals.cje.a035212.

4. Erokhin, V. and Gao, T. (2018), Competitive advantages of China's agricultural exports in the outward looking belt and road initiative in China's Belt and Road Initiative: Changing the Rules of Globalization, eds. W. Zhang, I. Alon, C. Lattemann. Palgrave Macmillan, London, UK. https://doi.org/10.1007/978-3-31975435-2.

5. Li, X. (2012), Technology, factor endowments, and China's agricultural foreign trade: a neoclassical approach. China Agricultural Economic Review, vol. 4, no. 1, pp. 105-123. https://doi.org/10.1108/17561371211196801.

6. Tocco, B., Bailey, A. and Davidova, S. (2013), The reallocation of agricultural labour across sectors: an empirical strategy for micro data, available at. https://www.ceps.eu/ceps-publications/reallocation-agricultural-labour-acrosssectors-empirical-strategy-micro-data/.

7. Matsuyama, K. (1992), Agricultural productivity, comparative advantage and economic growth. Department of economics, Northwestern University. Journal of Economic

$$
\text { Theory, }
$$
no. 58 ,

pp.

317-334. 
http://web.iitd.ac.in/ debasis/Lectures_HUL737/papers/paper2_JET\%201992.pdf

8. Dullien, S. (2005), China's Changing competitive position: lessons from a unit-labor-cost-based REER. EconWPA, International Trade Series, University Library of Munich, Germany. http://129.3.20.41/eps/it/papers/0502/0502016.

9. Zhao, Z. and Zhang, K. H. (2007), Chinas industrial competitiveness in the world. The Chinese Economy, vol. 40(6), pp. 6-23. https://doi.org/10.2753/CES10971475400601.

10. Tong, S. Y. and Chong, C. (2010), China-Asean free trade area in 2010: a regional perspective. EAI Background Brief, no. 519. East Asian Institute. National University of Singapore, Singapore.

11. Eppler, U., Fritsche, U. R. and Laaks, S. (2015), Urban-rural linkages and global sustainable land use. Globalands Issue Paper, International Institute for Sustainability Analysis and Strategy, Berlin, Germany. Available at: http://iinas.org/tl_files/iinas/downloads/land/IINAS_2015_Urban-

Rural_Linkages_Issue_Paper.pdf.

12. Ilbery, B. and Maye, D. (2005), Food supply chains and sustainability: evidence from specialist food producers in the Scottish/English borders. Land Use Policy, vol. 22, is. 4, pp. 331-344. https://doi.org/10.1016/j.landusepol.2004.06.002.

13. Jarosz, L. (2008), The city in the country: growing alternative food networks in metropolitan areas. Journal of Rural Studies, vol. 24, is. 3, pp. 231-244. https://doi.org/10.1016/j.jrurstud.2007.10.002.

14. Renting, H., Marsden, T. and Banks, J. (2003), Understanding alternative food networks: exploring the role of short food supply chains in rural development. Environment and Planning A: Economy and Space, vol. 35, is. 3, pp. 393-411. https://doi.org/10.1068/a3510.

15. Feagan, R. (2007), The place of food: mapping out the «local» in local food systems. Progress in Human Geography, vol.31, is. 1, pp. 23-42. https://doi.org/10.1177/0309132507073527.

16. Marsden, T. (2010), Mobilizing the regional eco-economy: evolving webs of agri-food and rural development in the UK. Cambridge Journal of Regions, Economy and Society, vol. 3, is. 2, pp. 225-244. https://doi.org/10.1093/cjres/rsq010.

17. Yang, C., Lukash, S. and QingRan, G. (2019), Econometric analysis on the relationship between agritourism development and economic growth. Journal of Economic and Management, no. 2, pp. 33-42. https://doi.org/10.33245/2310-92622019-151-2-33-42.

18. He, Luyao, Song Xiaowen (2019), Research on the relationship between agricultural products export and agricultural economic growth. China marketing, vol. 22 , no. 9 , pp. 56-57, 74 .

19. Liang, D. (2017), An empirical analysis of the impact of China's agricultural exports on economic growth. National Circulation Economy, vol. 10, no. 5, pp. 1112. 
How to cite this article? Як цитувати цю статтю?

Стиль - ДСТУ:

Maslak N., Lei Z., Xu L. Analysis of agricultural trade in China based on the theory of factor endowment. Agricultural and Resource Economics. 2020. Vol. 6. No. 1. Pp. 50-61. URL: http://are-journal.com.

Style - Harvard:

Maslak, N., Lei, Z. and Xu, L. (2020), Analysis of agricultural trade in China based on the theory of factor endowment. Agricultural and Resource Economics, vol. 6, no. 1, pp. 50-61, available at: http://are-journal.com. 